ショートペーパ

\title{
触覚を利用した自動車用補助計器
}

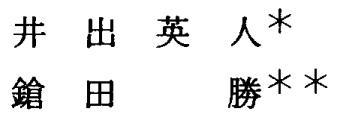

\section{An Assistant Instrument of Automobiles Using Tactile Sense}

\author{
Hideto IDE* ${ }^{*}$ Masaru YARITA**, \\ * Aoyama Gakuin Univ. \\ ** Nihon Kohden Corp.
}

\section{absutract}

\begin{abstract}
Human beings depend mostly on visual sensory information to recognize their environment. There are many devices which provide vibratory sensation to the skin but a few use vibratory sensation for practical application.

In this study, the vibration pattern is produced by a $16 \times 6$ array of small vibrator $(\mathrm{PZT})$ reeds $(50 \mathrm{~Hz})$ and the entire array $\mathrm{fits}$ on thumb. This apparatus can be used by the driver who can recognize the correct order of the characters from the motion of the vibrator points.
\end{abstract}

\section{1. はじめに}

人が外界から脳で受ける全ての情報のうち, 圧 倒的な役割をしめるのは視覚からの情報である ${ }^{1)}$. これが自動車を運転している時であればなおさら のことである。

自動車を運転しているときの視覚情報には, 前 方の先行車の車間距離, 左右のサイドミラーやル ームミラーによる後方視界，また車内に打いては 自車の速度やエンジン回転, 残燃料, 水温, 時計 などがある．このらち，車内の前面パネルからは ぞの程度の情報を得るかを推定する走行時の視線 配分はすでに谷島ら ${ }^{2)}$ が詳細なデータを報告して いる。

計器類のらち, スピードメータが 76〜92\%でタ

平成 2 年 2 月 13 日受付

* 青山学院大理工学部

₹ 157 東京都世田谷区千歳台 $6 丁$ 丁目 16 番 1 号

**日本光電

于 161 東京都新宿区西落合 1 丁目 31 番 4 号 キーワード：触覚 (tactile sense) 自動車計器 (automobiles instrument) 文字読取補助 (reading aid)
コメーターが 7.1〜21.2\%の視認である.

また，1つの計器に対する視線の固定時間は 0.5 〜 秒, 被験者の $30 \%$ が 2 秒ぐらい見つめている 場合もある.

免許取得者の増加に交通事故 女年々増加傾向に ある現在，スピードメータを視覚以外の感覚で代 行すればかなり視認に余裕ができ，より安全に運 転することができる。

本研究では, 触覚を利用した補助計器を製作し 貴重なデータを得ることができたので報告する. な拉，音声を利用しないのは装置の大型化，技術 的にまだ困難であり，また聴覚はラジオ等他から の情報のため空けておくため触覚を利用した。

\section{2. 装置}

2.1 刺激素子

皮虑受容器の時間的要因の諸特性を考虑し, 特 定の部位に定常的な感覚を引き起こし, 必要情報 を有効に伝達させるために振動子を用いた。ここ 
では駆動電流が少なく低消費電力で済むピエゾ素 子 $(\mathrm{PZT})^{3), 4)}$ を利用した。

図 1 に PZT 振動子の概略を示す。また図 2 に PZT 振動子の特性を示す. $10 \mathrm{~V}$ の駆動電王で 2 $\mu \mathrm{m}$ の振幅が得られた。この振幅測定はバイブロ メータと FM 振動計 ${ }^{5)}$ で検出した。

\section{2 触知盤の構成}

図 1 (a)に示すように, 振動子の端には直径 0.5 mmのピフノ線を用い接触子とした。図 1 (b)に使用 法を示す。

弁別閾 ${ }^{1), 5)}$ が $1.8 \mathrm{~mm}$ 以下であるため刺激素子の 間隔は振動の多い車の中で使用するため $2 \mathrm{~mm}$ とし た. 自動車が走行中の速度を表示させるためには， 最低でも 2 桁は数字を表示させなければならない ので表示部は $6 \times 8$ の 48 ドットを $2 つ$ 並べ 96 ドッ トとした。触知盤の試作器を写真 1 に示す。表示 は10位，1位の順に示され，1桁の場合10位は提 示しない，車への装着を写真 2 に示す．本触知盤 の大きさは $10 \mathrm{~cm} \times 6 \times 2.5$ であり重さは $120 \mathrm{~g}$ である. 刺激素子マトリックスは大人の指先に合 せて製作したが，女性には少し小さい。しかし被 験者も指先を少しずつ移動させることによりマト リックスの大小の影響は無い。

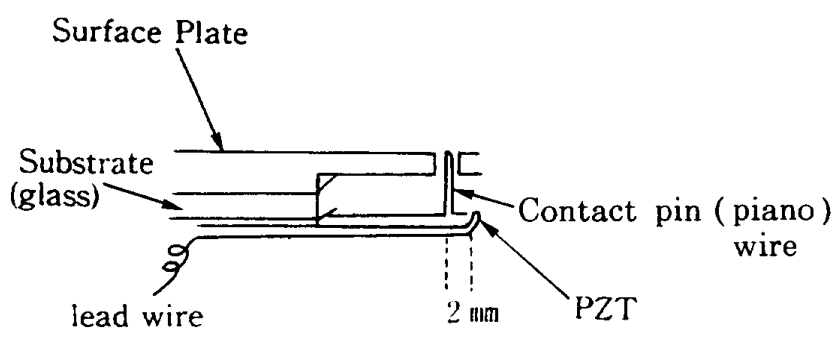

(a)

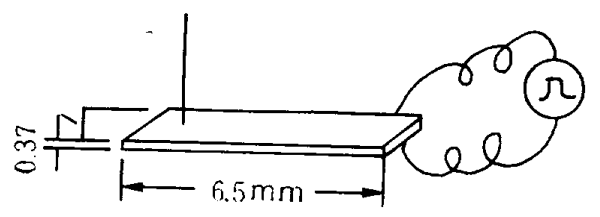

(b)
図 1 PZT 振動子

Fig.1 PZT vibrator

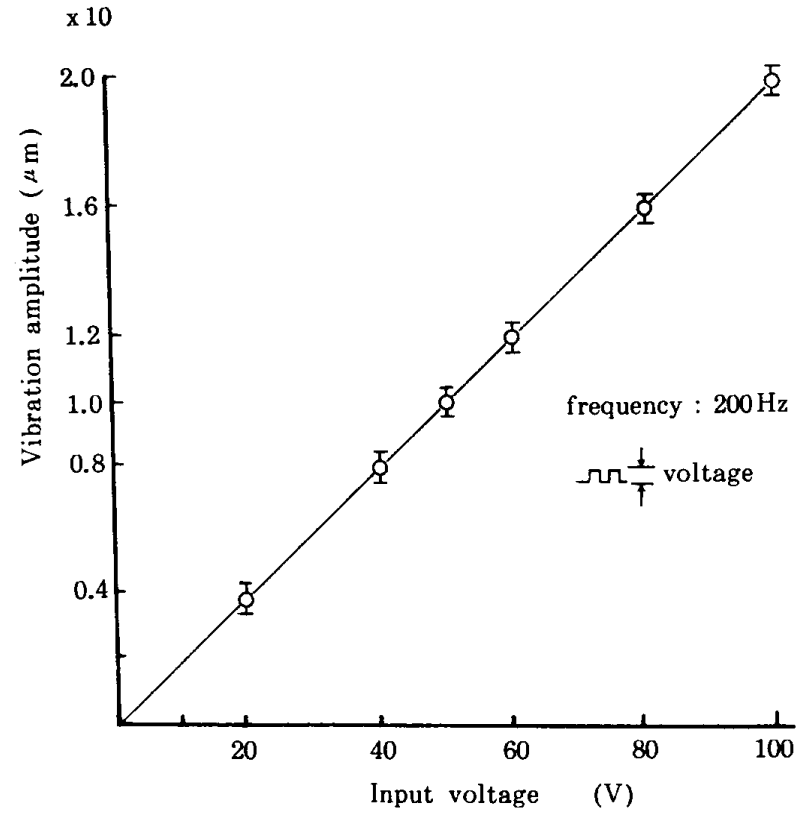

図 2 振動子の入出力特性

Fig.2 Characteristic of input-output

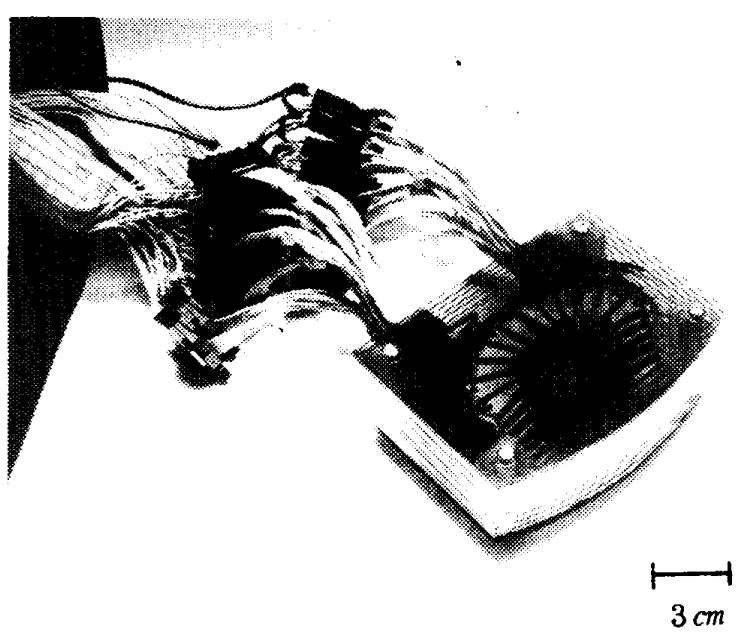

写真 1 装置の構 造

Photo 1 Construction of apparatus

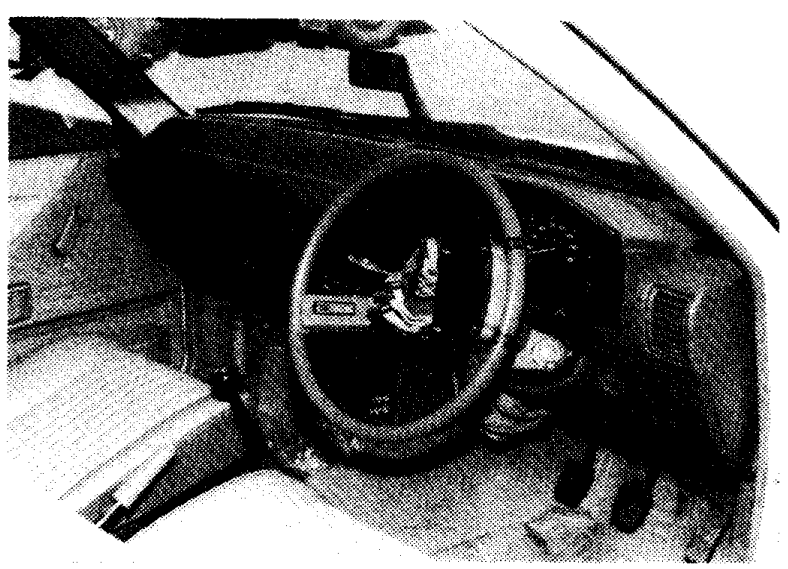

写真 2 装置の装着

Photo 2 Place of apparatus 


\section{3 試作装置}

図 3 亿試作装置のブロック図を示す。

タコメータより取り出した信号をメモり内の文 字情報交換部に入れ，マイクロュンピュータによ り $6 \times 8$ のマトリクスに変換し, 対応する数字, 文 字データを書き順通り ${ }^{6), 7)}$ に順次引き出し, 振動 子を選択する。

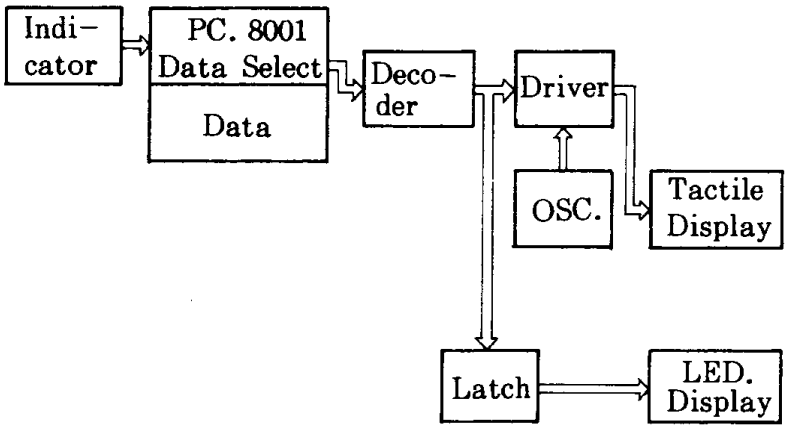

図 3 試作装置の構成図

Fig.3 Block diagram of apparatus

\section{3. 実験方法および結果}

本器を用い, 認識実験を行った。被験者は免許 所持者 30 名 (内女性 2 名) である. 年令は 18〜 30 才である. 同被験者により, 最も触知し易い基本 周波数，扣よび 1 点あたりの最適触知時間の測定 を行った，使用した指は中指，人差指である．図 4,5 に結果を示す。四から最適周波数は $50 \mathrm{~Hz}$ ， 最適触知時間は $0.2 \sim 0.3 \mathrm{sec}$ であることがわかる. しかし被験者によりパラメータは変わるので，試 験は被験者の最も高認識率を得られたパラメータ を用いた。

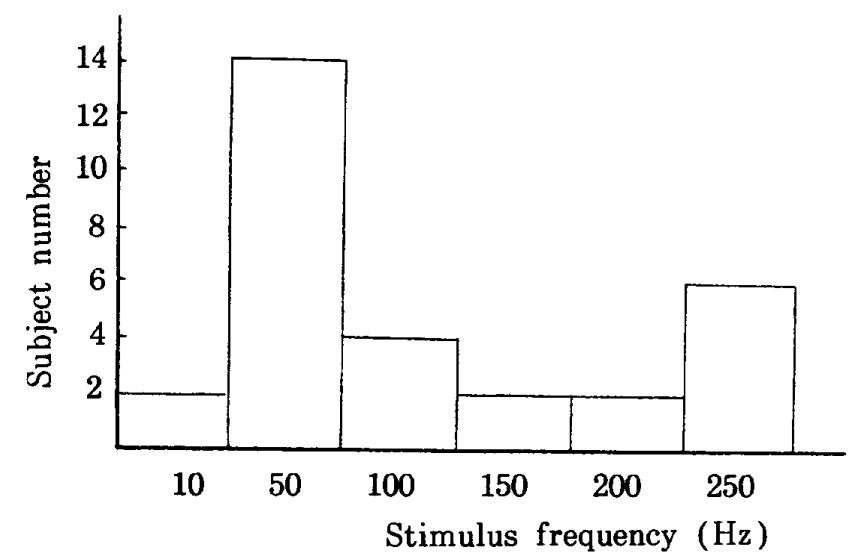

図 4 周波数による正答率

Fig.4 Correct rate of the frequency

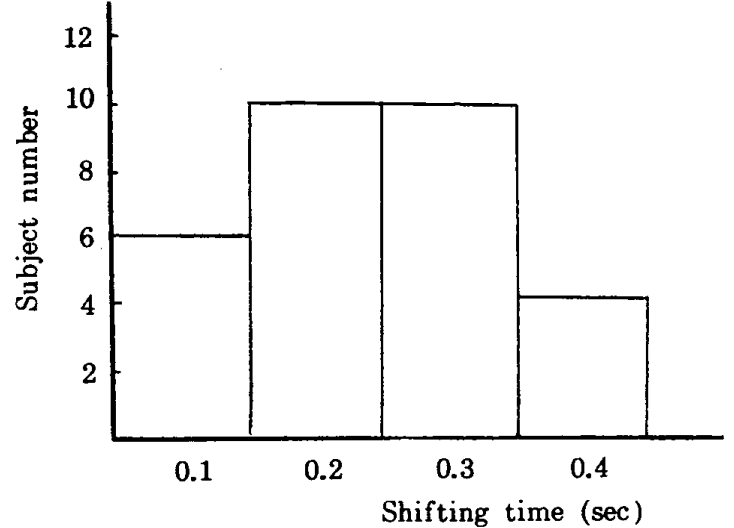

困 5 移動点の速さによる正答率

Fig. 5 Correct rate of the moving point

読み取り試験（運転停止中）を始める前に 5〜 10 分の学習を行ない, 学習中は間違った答の場合 は正しい答を教える方法を用いた。1文字ずつ， 1〜2 分の間を置いて無作為に提示した． 1 文字当 たり約 3 秒で終るようにし，同じ事を 10 回ずつ 2 日にかけて行った，練習時間に従い1文字を構成 する点の数によって 1 文字当りの提示時間が決ま ることからこれれよっても文字の判別はできる ようになった。

運転停止中では数十分の練習で容易に認識でき るようになった。

実際運転中 $50 \mathrm{~km} / \mathrm{h}$ 以下走行での結果を表 1 に 示す。実験中はメータ部分を被験者に見せず触覚 のみで判断してもらった。中央高速と 20 号線で 測定した。被験者 A. B と 30 名平均を示した。八 ンドルの操作の頻度により多少の影響はあった。 しかし直線コース等では問題はない。

表 1 数字の正答率

Table 1 Correct rate of the character identification

\begin{tabular}{|c|c|c|c|}
\hline Subject & A & B & $\begin{array}{c}\text { Sub.30 } \\
\text { Average }\end{array}$ \\
\hline Stimulus & & $100 \%$ & 100 \\
2 & $100 \%$ & $100 \%$ & 100 \\
3 & 80 & 90 & 90 \\
4 & 100 & 90 & 95 \\
5 & 80 & 90 & 88 \\
6 & 80 & 80 & 84 \\
7 & 100 & 100 & 100 \\
8 & 100 & 100 & 100 \\
9 & 80 & 90 & 93 \\
0 & 100 & 100 & 100 \\
\hline
\end{tabular}




\section{4. 結 び}

数字に打いては走行中ですほとんどの文字が 90 〜 $100 \%$ の正答率を得た. $100 \mathrm{~km} / \mathrm{h}$ 以上の表示に ついてもスピード感覚により表現できるため 2 ケ タ表示で充分であった。 また運転中の緊張による 発汗作用があっても書き順表示のため闘值変動の 影響は無かった。しかし文字提示に 3 秒程かかる 問題点がある。実用化に向けて現在更に研究中 ${ }^{8)}$ である。また，リハビリテーション分野への応用 として電動車イス, 各種計器の提示等への応用が できる.

終りに，被験者になられた皆様に感謝します。 製作にあたり御助力いただいた卒研生三沢賢哉君 に感謝する。

\section{参 考 文 献}

1）井出英人：星宮望, 石井直宏, 塚田稳, 生体情報 工学, 193-228, 森北出版 (1988)

2) 谷島一嘉：最近の車の前面パネルの人間工学的検 討, 人間工学, 21 (1)，43-46 (1985)

3) 井出英人：盲人用カラー文字訓練器, 電子通信学 会論文誌, J67-C (5)，496-497 (1984)

4) Ide, $\mathrm{H}$ \& Ishiba, $M$ : Color character trainer aid for the blind, IECE of Japan, E69 (6), 730-731 (1986)
5) 井出英人：皮膚振動感覚の温度依存性とそのモデ ル,バイオメカニズム， 7, 50-58, 東大出版会 (1984)

6) 井出英人：視覚代行器への文字入カインターフェ イス, 第 8 回感覚代行シンポジウム, 13-16 (1982)

7）井出英人, 石羽正人：一点一画筆順による文字認 識装置, 電子情報通信学会, MBE 86-98, 33-38 (1987)

8）特許申請中 (1990. 1)

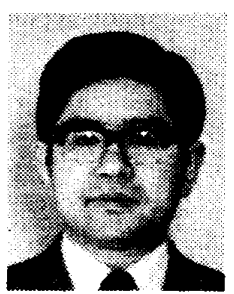

井出英人（いで ひでと） 昭和 45 年工学院大学大学院修士課程修了 (電 子専攻) 昭和 46 年青山学院大学理工 学部電気電子工学科講師, 助教授を経 て現在教授および学生部長. 昭和 50 年工学博士, 昭和 60 年 UCLA応用科 学科客員研究員, 昭和 61 年 UCLA 脳研究所客員教授. 感覚の計測, 感覚代行, 脳研究について興味を持って いる. 現在ロボット,コンピュータによるパターン認 識の応用に関する研究に従事. 日本ロボット学会, 電 気学会, 日本 $\mathrm{ME}$ 学会, 電子情報通信学会, 計測制御 学会の各会員.

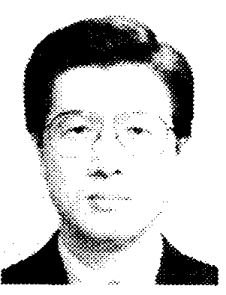

䥊田 勝（やりた まさる） 昭和 42 年工学院大学電子工学科卒, 同年日本 光電 $(\mathrm{KK})$ 入社, 昭和 $52 \sim 53$ 年 MIT 客員研究員, 現在日本光電第一技術部 部長, $\mathrm{ME}$ 機器の開発に従事, 日本 $\mathrm{M}$ $\mathrm{E}$ 学会会員, 日本神経学会などの会員. 